\title{
Acquired Pure Red Cell Aplasia (Prca) Responding to Erythropoietin Therapy in HIV Disease
}

\author{
Rama Bhat ${ }^{1}$, Raghavendra Rao ${ }^{2}$, Savio D'Souza ${ }^{3}$, Velagapudi Raja Mounika ${ }^{4}$, Srikar Allada ${ }^{4}$ and Ruchee Khanna ${ }^{5}$ \\ ${ }^{1}$ Professor, Department of Medicine, Kasturba Medical \\ College, Manipal University, India.
}

${ }^{2}$ Assistant Professor,Department of Medicine, Kasturba

Medical College, Manipal University, India.

${ }^{3}$ Senior Resident,Department of Medicine, Kasturba Medical College, Manipal University, India.

Corresponding author

Rama Bhat, Professor, Department of Medicine, Kasturba Medical College, Manipal University, India.

${ }^{4}$ postgraduate student, Department of Medicine,

Submitted: 09 Mar 2017; Accepted: 17 Mar 2017; Published: 07 Aug 2017

Kasturba Medical College, Manipal University, India.

${ }^{5}$ Associate Professor, Department of Pathology, Kasturba
Medical College, Manipal University, India

\section{Introduction}

Acquired pure red cell aplasia (PRCA) is characterized by the presence of an acquired normochromic, normocytic, anemia associated with a complete disappearance of reticulocytes and erythroid precursors in the marrow and normal production of myeloid cells and platelets. Mediators of suppression [1].

In approximately $60 \%$ of patients with PRCA serum inhibits erytroid progenitors in vitro. The target antigen is usually not known; but in few cases it is erythropoietin. Common causes of acquired PRCA include drugs, autoimmune disorders, and infections, lymphoid and myeloid malignancies. Erythropoietin antibody associated PRCA has been described in patients receiving recombinant therapy. We report a case of severe anaemia with marked selective suppression of erythroid precursors in a patient with HIV infection, with no other cause, responding dramatically to erythropoietin.

Case

A 60 year old patient with HIV disease on ART since 3 years presented with severe fatigue and chest pain. He was diagnosed to

have severe anaemia and non ST elevation myocardial infarction which was managed conservatively. His haemoglobin was $3.5 \mathrm{gm} \%$ with normal leucocyte and platelet counts. He had no lymphadenopathy or hepatosplenomegaly. CD4 count was 584 /c.mm and HIV viral load was 51 copies. Antinuclear antibody test was strongly positive in filamentous pattern suggestive of tropomyosin.He was transfused 3 units of packed.

Redcells. Zidovudine was thought to be the cause of anaemia and ART was changed to Tenofovir, lamivudine and efavirenz. Patient returned 3 weeks later with severe anaemia. A bone marrow study was done which showed selective suppression of erythroid precursors. Parvovirus serology was negative. Lamivudine was substituted with emtricitabine, discharged after packed red cell transfusion. He returned in 4 weeks with severe anaemia. ART was stopped for 4 weeks with no response. He was given a course of corticosteroids but had persistent anaemia. Antiretroviral therapy was continued with weekly erythroietin injections of 4000 units. He responded dramatically with normalisaton of haemoglobin in 4 weeks.

\begin{tabular}{|c|c|c|c|c|c|c|c|c|c|c|c|c|c|}
\hline Date & Hb g/dL & $\begin{array}{c}\text { TLC } \mathrm{x} \\
10^{3} / \mathrm{E} \mu \mathrm{L}\end{array}$ & $\begin{array}{c}\text { Differential count } \\
\mathrm{N} / \mathrm{L} / \mathrm{M} / / \mathrm{B}\end{array}$ & $\begin{array}{c}\text { PLAT } \mathrm{x} \\
10^{3} / \mu \mathrm{L}\end{array}$ & RETIC\% & $\begin{array}{c}\text { CD4 } \\
(\mathrm{cells} / \mu \mathrm{L})\end{array}$ & $\begin{array}{c}\text { HIV } \\
\text { RNA }\end{array}$ & CREAT & UREA & BIL & AST & ALT & ALP \\
\hline $7 / 10 / 16$ & 3.5 & 3.0 & $38.3 / 47.4 / 13.3 / 0.7 / 0.3$ & 212 & & 566 & & 0.7 & 24 & 0.2 & 14 & 14 & 143 \\
\hline $20 / 2 / 16$ & 3.5 & 6.4 & $58.5 / 30.1 / 8.1 / 2.9$ & 322.0 & 0.11 & $\begin{array}{c}\text { HIV-1 } \\
\text { RNA Viral } \\
\text { load:51 } \\
\text { copies/mL }\end{array}$ & & & & & & & \\
\hline $29 / 03 / 16$ & 3.9 & 5.5 & $57.1 / 32.6 / 8.2 /$ & 282.0 & & & & & & & & \\
\hline $6 / 5 / 16$ & 3.9 & 5.4 & $67.5 / 26 / 5.4 / 1 / 0.1$ & 236 & & & & & & & & & \\
\hline $27 / 06 / 16$ & 13.8 & & & & & & & & & & & & \\
\hline $29 / 8 / 16$ & 15.0 & 6.3 & $48 / 37.9 / 6.5 / 7.2 / 0.4$ & & & & & & & & & \\
\hline
\end{tabular}




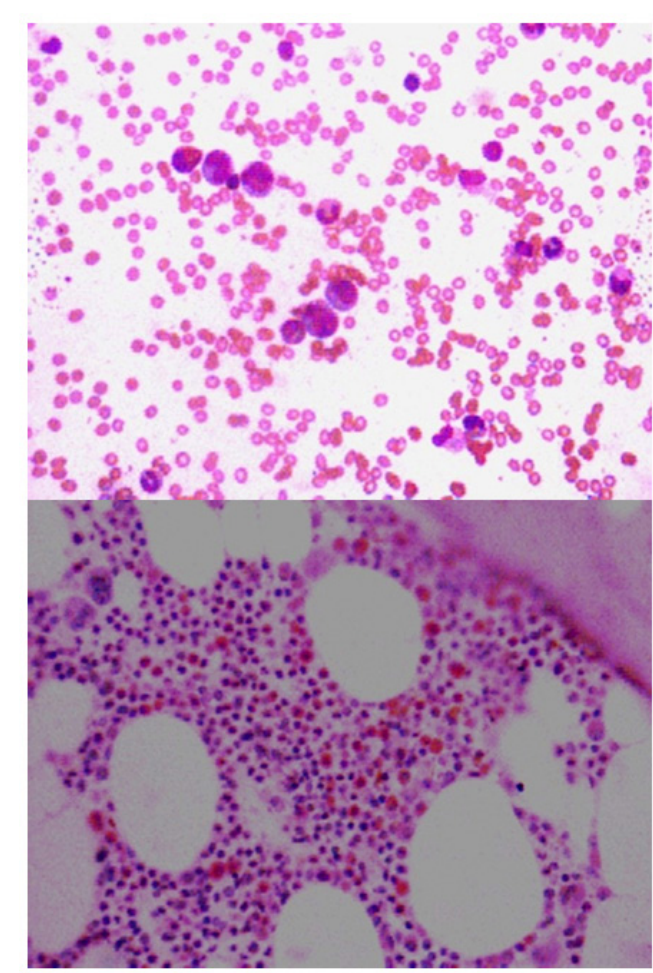

Figure 1: Bone marrow smear showing absence of red cell precursors

Bone marrow aspiration was repeated 8 weeks after starting erythropoietin therapy which showed reactive marrow with erythroid regeneration.

\section{Discussion}

Anaemia in HIV disease is common and is usually attributed to antiretroviral therapy, secondary infections, neoplasms or the HIV infection itself. Our patient had selective suppression of erythroid cells for almost one year with severe anaemia requiring frequent transfusions. His viral load was suppressed and anaemia persisted even after stopping the drugs including zidovudine and lamivudine. Bone marrow showed selective suppression of erythroid series with increased myeloid series. This was thought to be infection related initially, but we could not find any cause. The dramatic response to exogenous recombinant erythropoietin is difficult to explain. HIV disease is associated with production various autoantibpodies due immune dysregulation. Casadevali et al has reported autoantibodies against endogenous erythropoietin in a patient with pure red cell aplasia [2]. The patient's serum inhibited the growth of erythroid colonies in vitro without inhibiting the growth of other progenitors and this inhibition was completely reversed by high concentrations of erythropoietin. Sispas NV et al has demonstrated anti-erythropoietin antibodies in $23.1 \%$ of HIV-1 virus infected patients and presence of these antibodies were associated with more prominent erythropoietin response to anaemia [3]. Dhiraj Bhattad et al has reported a case of suspected pure red cell aplasia in HIV infected patient responding to steroid theray [4]. Our patient also had antinuclear antibody positivity which may be an indirect evidence of immune dysregulation. We conclude that our patient had a presentation like acquired PRCA with entirely different clinical course in the form of response to recombinant erythropoietin which is not reported so far.
References

1. Jaroslaw P. Maciejewski, Ramon V. Tiu (2013) Acquired pure red cell aplasia, in Hematology:Basic Principles and Practice. Chapter 30: 383-404.

2. Nicole Casadevali, Evelyne Dupuy, Pascale Molho-Molho Sabatier, Gerard Toobelem, Bruno Varet, et al. (1996) Autoantibodies against erythropoietin ia patient with pure red cell aplasia; N Engl J Med 334: 630-633.

3. Sipsas NV, Kokori SI, Ionnidis JP, KyriakiD, Tzioufas AG, et al. (1999) Circulating antibodies to endogenous erythropoietin and risk for HIV-1 related anaemia J Infect Dis 180: 2044-2047

4. Bhattad D, Kulkarni V, Bhave A, Balasubramanian M, Upase DP, et al. (2013) Refractory Anaemia in an Immunocompromised Patient - What is it? J Assoc Phys India 61: 673-675.

Citation: Rama Bhat, Raghavendra Rao, Savio D'Souza, Velagapudi Raja Mounika, Srikar Allada and Ruchee Khanna (2017). Acquired Pure Red Cell Aplasia (Prca) Responding to Erythropoietin Therapy in HIV Disease. Journal of Medical \& Clinical Research 2(3):1-2.

Copyright: $\odot 2017$ Rama Bhat. This is an open-access article distributed under the terms of the Creative Commons Attribution License, which permits unrestricted use, distribution, and reproduction in any medium, provided the original author and source are credited. 